Review article

\title{
Effects of insect growth regulators on honey bees and non-Apis bees. A review
}

\author{
Jean-Noël TASEI* \\ Unité de Recherches de Zoologie, INRA, 86600 Lusignan, France \\ (Received 26 December 2000; revised 17 May 2001; accepted 24 July 2001)
}

\begin{abstract}
The insect growth regulators (IGRs) are ecdysone or juvenile hormone mimics, or chitin synthesis inhibitors. They are more likely to be hazardous to larval insects than to adults. Application of JH mimics to adult honey bees may affect foraging behaviour and some physiological traits. Topical and feeding tests revealed that application of IGRs to larvae may result in death and larval ejection by workers, malformed larvae and pupae with typical rimmed eyes, or malformed adults. Several laboratory "larvae tests" using artificially contaminated diets have been described for honey bees and bumble bees. Field and cage methods have also been published for honey bees and bumble bees respectively. Diflubenzuron was generally safe for honey bee brood in fields treated at 35 to $400 \mathrm{~g} \cdot \mathrm{ha}^{-1}$ a.i. and harmful to bumble bees at $300 \mathrm{~g} \cdot \mathrm{ha}^{-1}$ a.i. Fenoxycarb was safe for bumble bees at $1200 \mathrm{~g} \cdot \mathrm{ha}^{-1}$ a.i. and hazardous to honey bees causing damage to honey bee brood at $140 \mathrm{~g} \cdot \mathrm{ha}^{-1}$.
\end{abstract}

insect growth regulator / honey bee / non-Apis bee / toxicity / risk assessment

\section{INTRODUCTION}

After Wigglesworth's pioneering studies performed during 1933-1940 (Wiggelsworth, 1972) on the control of insect growth by endocrine organs, Williams (1956) suggested that in addition to their theoretical interest, juvenile hormones could be accurately identified, then synthesised and used as insecticides. His prospects have been achieved since several commercial compounds called insect growth regulators or IGRs, have been used in insect pest control for more than 25 years. These insecticides of the third generation appeared after the early generation of arsenates, insecticides of mineral origin, and the second generation of organic synthetic compounds such as DDT. The mode of action of IGRs is quite original since they are not stomach poisons and they do not exhibit neurotoxicity but they disrupt moulting process or cuticle formation. Larval

* Correspondence and reprints

E-mail: tasei @ lusignan.inra.fr 
characters are maintained by the juvenile hormones $(\mathrm{JH})$ which are secreted by corpora allata. The $\mathrm{JH}$ are hormones of isoprenoid nature which prevent the breakdown of the thoracic gland (Wigglesworth, 1972). Pupal moulting is determined by a circulating hormone: the moulting hormone, secreted by the prothoracic glands which are activated by neurosecretory cells. This hormone triggers changes in the epidermis and deposition of the new cuticle. The purified form, of steroid nature is called ecdysone. Similar substances can be isolated from many plants. IGRs are commercial hormones mimics that influence moulting as hormones do, acting at the cellular level in various ways depending on their chemical constitution: tebufenozide influences moulting as ecdysone does, while pyriproxyfen and fenoxycarb are JH mimics. A third class is that of chitin inhibitors such as diflubenzuron, flufenoxuron, hexaflumuron, and lufenuron. In addition, a natural substance from neem tree, Azadirachta indica, proved to be a potent IGR (Rembold et al., 1980). According to Engels (1990) IGRs cause little or no damage to adult honey bees and generally the typical effects of these compounds can be seen after the moult of the exposed stage. All natural or synthetic compounds with IGR properties may be suspected of being hazardous to the brood of Apis or non-Apis bees since their larvae can be exposed to insecticides by an oral route. Davis (1989) contributed to the understanding of the oral pathway of insecticides, mediated by adult nurse honey bees which regurgitate honey sac content to feed larvae. In solitary bees, George and Rincker (1985), Tasei and Carré (1987), and Tasei et al. (1988), showed that Megachile rotundata Fabr. females provisioning their nest with pollen and nectar can also transfer insecticides to their larvae via the food stored in the cell prior to egg laying.

Most of scientific articles on IGR effects on bees are concerned with Apis mellifera $\mathrm{L}$. They describe the symptoms observed on larvae, and report on various methods to test the toxicity of different compounds to adults or larvae or to assess the risks of field treatments. Fewer articles report studies on nonApis bees, most of which are concerned with the bumble bee, Bombus terrestris L.

\section{EFFECTS OF IGRS ON HONEY BEES}

\subsection{Symptoms of IGR intoxication in adults}

The effects of juvenile hormone mimics such as methoprene were studied on workers by Redfern and Knox (1974). They tested this chemical, formulated in acetone, by topical application on adult workers lightly anaesthetised and did not find any mortality for concentrations ranging from 1 to $1000 \mu \mathrm{g} / \mathrm{bee}$. Robinson (1985) also applied methoprene dissolved in acetone topically on workers which were marked and reintroduced into their colony for behavioural observations. He found that bees treated with $250 \mu \mathrm{g}$ of $\mathrm{JH}$ analogue started foraging earlier than control ones. Lower doses, 25 and $2.5 \mu \mathrm{g}$ caused no significant effect. Foraging performances estimated by the number of foraging trips per hour and the duration of the foraging period were not influenced by methoprene whereas the production of two alarm pheromones was induced prematurely. Jaycox et al. (1974) tested another synthetic JH mimic, the LawWilliams mixture. They injected experimental doses ranging from 10 to $200 \mu \mathrm{g} / \mathrm{bee}$, between metasomal tergites, using either olive or mineral oil as a carrier and found bees ate less pollen after injection of $\mathrm{JH}$ mimic. Treated bees could not develop their hypopharyngeal glands and started to move out of the brood nest, to guard the hive entrance, to fly and to collect pollen, sooner than control bees. There was a dose-effect relation in the onset of activity outside the colony. JH mimic treatment also reduced longevity by $39 \%$. Rutz et al. (1974) applied JH III and the IGR triprene on freshly 
emerged workers by feeding or injection and found that both hormones caused a reduction in the total protein content of the haemolymph and a change in the form of leucocytes. At a high dose of JH III ( $1 \mu \mathrm{g} / \mathrm{bee})$ the hypopharyngeal glands regressed which hampered larva feeding by workers. Triprene at $1 \mu \mathrm{g} / \mathrm{bee}$ shortened the life of queen-less workers. Atkins et al. (1976) measured the effects of hundreds of pesticides on bees and listed active substances and formulations according to their hazards to bees in field tests for commonly used materials. For less frequently used compounds they referred to laboratory data. Dimilin ${ }^{\circledR}$, formulated with diflubenzuron, one of the most common commercial IGR appeared in the group of the "relatively nontoxic" insecticides. Usha and Kandasamy (1986) exposed Apis cerana Fabr. for 90 min to surfaces treated with several insecticides including diflubenzuron. As no mortality occurred even at $10000 \mathrm{mg} \cdot \mathrm{kg}^{-1}$ the authors concluded that this chitin synthesis inhibitor was the safest and should be recommended for integrated pest management. Diflubenzuron was also tested on newly emerged adults of $A$. mellifera and $A$. cerana indica by Gupta and Chandel (1995). They found that topical applications of $100 \mu \mathrm{g}$ doses were tolerated by treated bees but resulted in a reduced weight gain. The same dose administrated per os proved fatal, but $50 \mu \mathrm{g}$ were tolerated and suppressed the development of hypopharyngeal glands in both species. This oral treatment also affected weight gain, indicating that at high doses, this IGR can be harmful to adults. Acute toxicity tests performed on adult $A$. mellifera with another IGR, flucycloxuron (Andalin ${ }^{\circledR}$ ) proved this material safe in integrated pest control (Ceparano and Job, 1989). Pyriproxyfen, applied at concentrations higher than $1.25 \mu \mathrm{g}$, to newly emerged workers, impaired vitellogenin synthesis in the haemolymph (Pinto et al., 2000). Gerig (1975) fed workers with pollen, artificially contaminated by the juvenile hormone analogue kinoprene and observed abnormal leucocytes, the inhibition of hypopharyngeal glands, the decrease of the total haemolymph proteins and the reduction of longevity.

\subsection{Symptoms of IGR intoxication in larvae}

After topical application of the juvenile hormone analogue methoprene on 3 and 5 day old larvae Hussein and Abdel-Aal (1978) observed malformations of the abdomen, wings and wax glands in adults. In addition, more than $50 \%$ of treated larvae were removed from their brood cell. Zdarek and Haragsim (1974) studied the morphogenetic action of 33 structurally unrelated $\mathrm{JH}$ analogues chemicals by applying them on worker bee larvae either during their feeding period or later. The early treatment induced the development of imaginal characters of queen and the late administration inhibited the differentiation of imaginal structures. Beetsma and Ten Houten (1975) tested JH I, II, III, IV, V and VI by mixing the compounds with the food supplied to small colonies or by spraying it on rapeseed flowering in a flight cage. After treatment with JH I, II, IV and V they did not observe any mortality in workers but found incompletely coloured adults with queenlike characters. With JH IV and V, the queens died and all larvae disappeared within the week following application. JH V inactivated hypopharyngeal glands of adult workers. Almost no brood was affected by JH III and VI, and JH I and II resulted in an increase of brood. Similar methods were used by Hrdy and Skrobal (1976) who found that application of JH I and JH II reduced brood quantity. Gerig (1975) found that kinoprene inhibited the development of hypopharyngeal glands.

Feeding small colonies with diflubenzuron reduced the amount of capped and uncapped brood while increasing the number of eggs laid (Chandel and Gupta, 1992) which was presumably a sign of an ovicidal 
action of this compound as demonstrated on other species by Grosscurt (1978). After addition of diflubenzuron to royal jelly fed to queen larvae Nitsch et al. (1994) observed that at the concentration $0.05 \%$, treated larvae either died or were ejected by workers. Even at the lowest tested concentration $0.00625 \%$, the authors found some larvae removed from their cells. When queens died before emergence they showed typical damage on head and thorax. El-Din et al. (1990) topically applied diflubenzuron and also two other IGRs, triflumuron and chlorfluazuron at the LD 25, to 3 day old larvae and reported reduced weight in emerging adults by 19.3 , 39.6 , and $29.1 \%$. When treated at LD 50 or LD 90, larvae were removed by nurse bees and no sealed brood could be found.

Observations were reported on the effects of fenoxycarb on honey bee brood after application on flowering fruit trees (Anonymous, 1989). The authors found that 8 to 20 days following treatment, contaminated and malformed larvae and pupae were removed outside the hive by workers. Ejected pupae had atrophied wings and an abnormally flat and short abdomen. According to Van der Steen and de Ruijter (1990), Gerig (1990) and Marletto et al. (1997), dead pupae showed typical eyes with a white or reddish rim on their inner border. Gerig also observed undeveloped wings and shrunk abdomen in young workers. Fenoxycarb applied to hives by various means resulted in ejection of malformed pupae and prepupae, which began 1 to 2 weeks after treatment and continued 2 to 3 months. Besides, this IGR predisposed the hives to attacks by the European foul brood and to sac brood (Marletto et al.,1992).

Teflubenzuron treatments in feeding and contact tests affected brood development as early as larvae hatching from eggs (Gromisz and Gromisz, 1996).

Two of the partially purified fractions extracted from neem seed (Azadirachta indica, Meliaceae), was tested by Rembold et al. $(1980,1982)$ on third instar larvae of workers. The application of both substances resulted in growth disruptions, causing malformations and high pupal mortality. The less pure fraction showed an anti-feedant effect but did not affect weight gain of larvae. One tenth of the dose effective for pests, caused disturbance in larval development of honey bees.

\subsection{Methods for testing the toxicity of IGRs to bee larvae}

Atkins and Kellum (1986) were convinced that pesticides could be deposited in the hive through contaminated pollen. Compounds which are hazardous to brood and likely to be transferred to hives by foragers are those which are absorbed slowly, those which are encapsulated, and those which are of low toxicity to adults and high toxicity to larvae. These authors were probably the first scientists to devise a method for testing the effects of pesticides on bee brood. Their "Bee Larval Morphogenic Test", devised in 1974 and unpublished at that time, allowed the assessment of the effects of pesticides on individual larvae inside the hive. In the experimental colony the queen was confined for $24 \mathrm{~h}$ in a small cage made of queen excluder material, covering 500 worker cells of an empty comb. Then the treatment solutions were applied to the food in the bottom of each cell with a microsyringe delivering $1 \mu \mathrm{l}$ droplets per cell. A sample of 100 larvae living in several horizontal adjacent rows was treated for each dilution of pesticide and a control was included in each test. The number of surviving treated and control larvae was assessed after cell capping. Before adult emergence, the experimental comb was removed from the hive and kept in an incubator at $35-37{ }^{\circ} \mathrm{C}$. After emergence, survival and amorphogenic effects were assessed. This brood toxicity test was applied to different age groups of larvae.

Barker and Taber (1977) reared bees from egg to adult using nurse workers selected 
from moved colonies containing no foragers. They considered bees suitable for nursing if they remained 2-3 h on a lone frame with eggs. Eggs of this experimental unit should be attended by approximately 250 nurse bees. The frame with eggs was introduced into a wooden box holding two other frames on either sides containing a pollen-sugar mixture making a dough. A caged virgin queen was added to the workers and the wooden box was held 10 days at $25{ }^{\circ} \mathrm{C}$ in the dark. Control or contaminated syrup was weighed and replaced every 5 days. After 10 days the brood was separated from the workers and incubated at $32^{\circ} \mathrm{C}$ for 10 days until emergence of adults which should be examined for morphological characteristics.

Naumann and Isman (1996) also used larvae reared by colonies after treatment. They applied the test substance on first and fourth instars which were in demarcated areas of combs containing at the beginning only first instar larvae. Series of 45 or 100 larvae were treated with each concentration. Treatment was applied by injecting $0.5 \mu \mathrm{l}$ of test solution into the larval food at the bottom of each cell. Six concentrations were used and frames were examined for the survival of first instar larvae 6 and 10 days after treatment and for the fourth instar larvae, 10 days after treatment and at adult emergence. The authors recommended to give the result as LD 50 expressed in active substance weight per body weight.

Wittman (1982) described the first version of a new "Apis-larvae-test" which enables the determination of the LC 50 of agrochemicals and in particular IGRs. The principle was to dissolve the compound in royal jelly and apply the food to groups of larvae of known age reared in strong colonies. Test areas comprised 50 larvae in the second, third and fourth instar. Each larva was fed $10 \mu \mathrm{l}$ of the test mixture. Six different concentrations of the test substance were applied in 3 or 4 series of 100 larvae each and the LC 50 was calculated by regression analysis. In their in vitro version of the in-hive "Apis-larva-test" Wittmann et al. (1985) used an artificial diet they fed to larvae of various stages. These larvae were grafted into $0.5 \mathrm{ml}$ depressions of titration trays, kept in the incubator. Engels (1990) used the same in vitro method and recommended applying the test substance mixed with the artificial diet to third or fourth instar larvae because they were easier to handle. He claimed this procedure provided highly reproducible LD 50s and LC $50 \mathrm{~s}$.

In his Apis-larvae-test Czoppelt (1990) reared larvae from the first to fifth instar in the incubator at $35^{\circ} \mathrm{C}$, on a semi-artificial diet consisting of a mixture of royal jelly, sugar solution and yeast extract (Rembold and Lackner, 1981). Young larvae were transferred into artificial cells to feed on the mixture and one day later into new cells where chemicals could be applied after dilution in royal jelly at concentrations ranging from 0 to $10 \mu \mathrm{g} \cdot \mathrm{ml}^{-1}$. Larval weight gain was measured during the $48 \mathrm{~h}$ period of intense growth between the fourth and the fifth instar. This method is an in vitro standard test allowing the assessment of larvicidal effects of IGR and observations of larval growth until pupation.

Van der Steen and de Ruijter (1990) described a feeding test and a field test. In the first test the pesticide was dissolved in a sugar solution which was fed to colonies. About 200 cells containing all stages from egg to pupa were marked by means of a transparent sheet. The larval stage was divided into young and old larvae. The mortality in each cell was checked once a week. In the field, test hives were placed in the crop at the beginning of flowering, $80 \mathrm{~cm}^{2}$ of brood cells were marked as in the feeding test, and a trap was fixed in front of the hives to collect dead pupae. The test substance was applied to the crop during its full bloom and the marked cells were checked three times a week until brood cells were empty.

Oomen et al. (1992) published the official method of the EPPO (European Plant 
Protection Organisation) for honey bee feeding tests with IGR insecticides. The principle was to feed colonies with 11 of a sugar solution containing the test substance at the concentration recommended for field use. The trial compared a test substance with an IGR reference and a pure sugar solution. Before the start of feeding, 300 cells per colony were marked, 100 with eggs, 100 with young larvae and 100 with old larvae. Brood development was checked once a week during 3 weeks following application. Dead pupae were counted in a dead bee trap fitted in front of the hives. Three replicates at least per product and per concentration should be performed. To describe brood development, it was recommended to mark each cell on an overhead sheet, using a colour code for each stage. Then, copies of the sheet should be used for further inspections and juvenile stages should be indicated by their colour code.

\subsection{Discussion of the methods}

The recommendations of the nine authors or groups of authors mentioned above are summarised in Table I. Toxicity tests comprise (a) in hive methods described by Barker and Taber (1977), Wittman (1982), Atkins and Kellum (1986), and Nauman and Isman (1996), (b) the in vitro methods of Engels (1990) and Czoppelt (1990). For risk assessment, field methods were described by Van der Steen and de Ruijter (1990) and Oomen, de Ruijter and Van der Steen (1992).

The in-hive tests required a unique application of test substance and implied permanent feeding by nurse bees. Therefore an influence of nursing can not be excluded and may result in low reproducibility of LD 50 s. Another source of variability lies in the syringe application into the brood cell where the contaminated food is both ingested by the larva and is in contact with its cuticule. This mixed action is also modified from one stage to another due to size variation.
It is more acceptable to use water or royal jelly as a dilution medium, than acetone (Atkins and Kellum, 1986) which may exert a variable negative influence on the treated larvae according to their stage. Barker and Taber's method was intermediate between in-hive and in vitro test, since the authors kept the experimental bees in the incubator and relied upon nurse bees to transfer the test substance from contaminated syrup to larvae. Nurse bee interference was likely to be reduced compared to free flying colonies since they have not access to food collected from outside.

Van der Steen and de Ruijter (1990) and Oomen et al. (1992) recommended in-hive tests where feeders enabled permanent or limited consumption of the test substance. Their tests can not be conducted when there is a high natural nectar flow because of the possible risk of storage of the contaminated solution in empty frames. The reproducibility of their tests depends on the external food resources which may influence the results due to a dilution effect of the test substance. Data recorded include only the percentage of dead or malformed individuals when a known concentration of formulated IGR is diluted in the sugar solution. A similar method for testing the short term and long term effect of a non-IGR insecticide on bee brood was published by Webster and Peng (1989).

The in vitro test described by Wittmann et al. (1985); Czoppelt (1990) and Engels (1990) requires artificial cells and artificial diets where yeast extracts replace pollen. Their procedure is that which ensures the highest reproducibility of LD 50s or LC 50s. Other authors published slightly different in vitro "Apis-larva-tests", in particular Davis et al. (1988), who studied the effect of non-IGR insecticides at adult sublethal levels on larval growth.

When considering the registration scheme, it is recommended to conduct an in vitro "Apis-larva-test" to estimate the toxicity of IGRs, then risk assessment of 
Table I. Methods for testing toxicity and hazards of IGRs to honey bees, according to authors.

\begin{tabular}{|c|c|c|c|c|c|c|c|c|c|}
\hline Authors & $\begin{array}{c}\text { Atkins } \\
\text { and Kellum }\end{array}$ & $\begin{array}{c}\text { Barker } \\
\text { and Taber }\end{array}$ & $\begin{array}{l}\text { Nauman } \\
\text { and Isman }\end{array}$ & Wittman & Engels & Czoppelt & $\begin{array}{l}\text { Van der Steen } \\
\text { and de Ruijter }\end{array}$ & $\begin{array}{l}\text { Van der Steen } \\
\text { and de Ruijter }\end{array}$ & $\begin{array}{c}\text { Oomen } \\
\text { de Ruijter } \\
\text { and Van der Steen }\end{array}$ \\
\hline Year & (1986) & (1977) & (1996) & (1982) & (1990) & (1990) & (1990) & (1990) & (1992) \\
\hline $\begin{array}{l}\text { Number } \\
\text { individuals } \\
\text { per test concentration }\end{array}$ & 100 la. $^{\mathrm{a}}$ & $\begin{array}{c}148-1083 \\
\text { eggs }\end{array}$ & 45-100 la. & $4 \times 100$ la & $4 \times 100$ la. & - & $\begin{array}{l}200 \\
\text { brood cells } \\
\text { (all ages) }\end{array}$ & $\begin{array}{l}80 \mathrm{~cm}^{2} \\
\text { brood cells } \\
\text { (all ages) }\end{array}$ & $\begin{array}{c}100 \text { eggs } \\
100 \text { young la. } \\
100 \text { old la. } \\
(\times 3 \text { colonies })\end{array}$ \\
\hline $\begin{array}{l}\text { Age of test } \\
\text { larvae }(\mathrm{d} \\
\text { or instar) }\end{array}$ & $\begin{array}{l}1-2 \mathrm{~d} \\
3-4 \mathrm{~d} \\
5-6 \mathrm{~d}\end{array}$ & all & $\begin{array}{l}1 \mathrm{st} \\
4 \mathrm{th}\end{array}$ & $\begin{array}{l}\text { 2nd } \\
3 \mathrm{rd} \\
4 \text { th }\end{array}$ & $\begin{array}{l}3 \mathrm{rd} \\
4 \text { th }\end{array}$ & all & $\begin{array}{c}\text { eggs } \\
\text { young }+ \\
\text { old larvae } \\
\text { capped cells }\end{array}$ & $\begin{array}{c}\text { eggs } \\
\text { young+ } \\
\text { old larvae } \\
\text { capped cells }\end{array}$ & \\
\hline $\begin{array}{l}\text { Rearing } \\
\text { conditions }\end{array}$ & $\begin{array}{l}\text { free } \\
\text { flying } \\
\text { colony ca }\end{array}$ & $\begin{array}{l}3 \text { frames } \\
25^{\circ} \mathrm{C} .10 \mathrm{~d} \\
\text { caged virgin queen } \\
\text { nurse bees }\end{array}$ & $\begin{array}{l}\text { free } \\
\text { flying } \\
\text { colony }\end{array}$ & $\begin{array}{l}\text { free } \\
\text { flying } \\
\text { colony }\end{array}$ & $\begin{array}{l}\text { incubator } \\
\text { artificial } \\
\text { cells }\end{array}$ & $\begin{array}{l}\text { incubator } \\
35^{\circ} \mathrm{C} \text {. } \\
\text { artificial cells }\end{array}$ & $\begin{array}{l}\text { free } \\
\text { flying } \\
\text { colony }\end{array}$ & $\begin{array}{l}\text { free } \\
\text { flying } \\
\text { colony }\end{array}$ & $\begin{array}{l}\text { free } \\
\text { flying } \\
\text { colony }\end{array}$ \\
\hline $\begin{array}{l}\text { Application } \\
\text { of test solution }\end{array}$ & syringe & $\begin{array}{l}\text { permanent } \\
\text { feeder }\end{array}$ & syringe & syringe & syringe & syringe & $\begin{array}{l}\text { permanent } \\
\text { feeder }\end{array}$ & $\begin{array}{c}\text { field } \\
\text { application }\end{array}$ & $\begin{array}{l}\text { feeder } \\
11 .\end{array}$ \\
\hline $\begin{array}{l}\text { Application } \\
\text { medium }\end{array}$ & $\begin{array}{l}\text { acetone } \\
\text { pure or } \\
\text { acidified }\end{array}$ & water & water & $\begin{array}{l}\text { royal } \\
\text { jelly }\end{array}$ & $\begin{array}{l}\text { artificial } \\
\text { diet }\end{array}$ & $\begin{array}{c}\text { royal } \\
\text { jelly } \\
\text { +yeast }\end{array}$ & water & flowers & water \\
\hline Insecticide grade & technical & formulated & formulated & formulated & formulated & formulated & formulated & formulated & formulated \\
\hline $\begin{array}{l}\text { Survival } \\
\text { assessment }\end{array}$ & $\begin{array}{l}\text { after } \\
\text { cell capping }\end{array}$ & $\begin{array}{c}\text { after } \\
\text { cell capping }\end{array}$ & $\begin{array}{l}\text { after } 6 \text { and } \\
10 \mathrm{~d} \text { or after } \\
\text { emergence }\end{array}$ & - & $\begin{array}{c}1,2,3 \\
4,7, \mathrm{~d} \\
\text { after treatment }\end{array}$ & permanent & $\begin{array}{l}\text { weekly } \\
\text { check } \\
3 \text { weeks }\end{array}$ & $\begin{array}{c}3 \text { times } \\
\text { per week }\end{array}$ & $\begin{array}{l}\text { weekly check } \\
3 \text { weeks }\end{array}$ \\
\hline $\begin{array}{l}\text { Reported } \\
\text { parameter }\end{array}$ & $\begin{array}{c}\mathrm{LD} 50 \\
\mu \mathrm{g} \cdot \mathrm{bee}^{-1}\end{array}$ & $\begin{array}{l}\text { concentration } \\
\text { with effect }\end{array}$ & $\begin{array}{c}\mathrm{LD} 50 \\
\mu \mathrm{g} \cdot \mathrm{g}^{-1} \text { bee }\end{array}$ & $\begin{array}{c}\text { LC } 50 \\
\mathrm{mg} \cdot \mathrm{kg}^{-1} \text { solution }\end{array}$ & $\begin{array}{r}\text { LC 50 } \\
\mathrm{n} \quad \text { LD 50 }\end{array}$ & $\begin{array}{l}\text { LC } 50 \\
\text { LD } 50\end{array}$ & $(\%)$ dead & $(\%)$ dead & $(\%)$ dead \\
\hline $\begin{array}{l}\text { Other } \\
\text { observations }\end{array}$ & $\begin{array}{l}\text { amorphogenic } \\
\text { effects }\end{array}$ & $\begin{array}{l}\text { malformed } \\
\text { individuals }\end{array}$ & $\begin{array}{l}\text { longevity } \\
\text { of adults }\end{array}$ & none & none & $\begin{array}{l}\text { malformed } \\
\text { individuals }\end{array}$ & $\begin{array}{l}\text { malformed } \\
\text { pupae }\end{array}$ & $\begin{array}{l}\text { malformed } \\
\text { pupae }\end{array}$ & $\begin{array}{c}\text { larvae } \\
\text { pupae adults } \\
\text { (dead bee trap) }\end{array}$ \\
\hline
\end{tabular}


registered concentrations should be performed with Oomen et al.'s field test (1992).

\subsection{Toxicity data on some IGRs}

\subsubsection{Fenoxycarb}

Fenoxycarb dissolved in a sugar solution at the rate of $100 \mathrm{mg} \cdot \mathrm{L}^{-1}$ and fed to colonies caused the death of almost all larvae and those which reached the pupal stage were malformed. At $200 \mathrm{~m} \cdot \mathrm{L}^{-1}$, all the larvae died (Van der Steen and de Ruijter, 1990). In Czoppelt's study (1991) all pupae died when the food contained $0.5 \mathrm{mg} \cdot \mathrm{kg}^{-1}$ fenoxycarb. This author found an LC 50 of $0.2 \mathrm{mg} \cdot \mathrm{kg}^{-1}$, i.e. $0.12 \mu \mathrm{g} \cdot \mathrm{larva}^{-1}$ while Nitsch and Vorwohl (1992) established several LD 50 for each caste larvae fed at the 2 day stage and found for queens, workers and drones 7 , 17 and $16 \mathrm{ng} \cdot$ larva $^{-1}$, respectively.

\subsubsection{Diflubenzuron}

Barker and Taber (1977) found in laboratory conditions that diflubenzuron mixed with syrup at concentrations $0.59,5.9$ and $59 \mathrm{mg} \cdot \mathrm{kg}^{-1}$ did not affect food consumption. Sealed brood was significantly reduced for the highest concentration $59 \mathrm{mg} \cdot \mathrm{kg}^{-1}$, while lower concentrations had no effect on brood. No abnormalities were observed in newly emerged adults in any treatment. Barker and Waller (1978) obtained similar results in field conditions when studying hives exposed to $100 \mathrm{mg} \cdot \mathrm{kg}^{-1}$ diflubenzuron in their water and to $60 \mathrm{mg} \cdot \mathrm{kg}^{-1}$ diflubenzuron in their syrup. They reported a higher egg laying in treated hives but interpreted this effect as a consequence of hatching failure or a compensation for killed larvae. Using field colonies in an area of limited bee forage, Stoner and Wilson (1982) fed the bees for 12 weeks with sugar cake contaminated with diflubenzuron and found the concentration of $1.0 \mathrm{mg} \cdot \mathrm{kg}^{-1}$ reduced sealed brood while $10 \mathrm{mg} \cdot \mathrm{kg}^{-1}$ reduced both sealed brood and the population of adults.
Concentrations lower than $1.0 \mathrm{mg} \cdot \mathrm{kg}^{-1}$ had no detectable effect on brood and adults. Tomic et al. (1985) feeding small colonies with contaminated syrup did not report damage on sealed or unsealed brood with concentrations of $5 \mathrm{mg} \cdot \mathrm{kg}^{-1}$ and $50 \mathrm{mg} \cdot \mathrm{kg}^{-1}$. Nation et al. (1986) used caged, small colonies for testing diflubenzuron in syrup at $10 \mathrm{mg} \cdot \mathrm{kg}^{-1}$ and did not see any reduction in the consumption of pollen and the quantity of brood reared. In the laboratory, Czoppelt and Rembold (1981) reported that topical application of $30 \mathrm{ng}$ diflubenzuron resulted in delayed larval development and dead prepupae. At doses of 50 and $100 \mathrm{ng}$, larval survival was less than $26 \%$ and prepupal death rate more than $35 \%$. In their feeding test, concentrations ranging from 0.6 to $1.2 \mu \mathrm{g} \cdot \mathrm{mL}^{-1}$ diflubenzuron resulted in reduced larval survival and a total failure of pupal stage. Larval growth was impeded at high concentrations (1.0 and $\left.1.2 \mu \mathrm{g} \cdot \mathrm{mL}^{-1}\right)$. The authors found a topical LD 50 of $50 \mathrm{ng}$ per larva and an oral LD 50 of $120 \mathrm{ng}$, which was contradictory to Chandel and Gupta's (1992) results who studied the toxicity of diflubenzuron to third and fourth larval instars. The topical LD 50s were 2.42 and $6.01 \mu \mathrm{g} \cdot \mathrm{larva}^{-1}$, respectively, for A. mellifera, and 1.49 and $3.65 \mu \mathrm{g} \cdot \mathrm{larva}^{-1}$, respectively, for A. cerana indica. LD 50 expressed per body weight showed a similar susceptibility of both species to the compound. Wittman (1982) found an LC 50 of $3.7 \mathrm{mg} \cdot \mathrm{kg}^{-1}$ diflubenzuron.

\subsubsection{Azadirachtin}

Rembold and Czoppelt (1981) studied the effects of azadirachtin on honey bee larvae. They purified the compound from neem seeds and treated third instar larvae by topical application. Larvae were fed with a royal jelly and yeast mixture and reared in the incubator. The lowest dose causing observable effects was $0.25 \mu \mathrm{g} \cdot$ larva $^{-1}$. Naumann and Isman (1996) did not use seed extracts with unknown amounts of 
azadirachtin but an emusifiable concentrate with an undiluted azadirachtin content of $46000 \mathrm{mg} \cdot \mathrm{kg}^{-1}$. Oral application of increasing doses of azadirachtin on first and fourth instar larvae resulted in larval ejection by nurse bees in a dose dependent manner. The LD 50 for both instars was $37 \mu \mathrm{g} \cdot \mathrm{g}^{-1}$ body weight and $61 \mu \mathrm{g} \cdot \mathrm{g}^{-1}$ body weight.

\subsubsection{Bay Sir $8514^{\circledR}$}

Herbert et al. (1986) prepared a pollen substitute containing $1,10,50$, and $100 \mathrm{mg} \cdot \mathrm{kg}^{-1}$ Bay Sir, which is a chitin synthesis inhibitor. At the two highest concentrations, bees fed for 12 weeks with the test diets were not able to rear brood despite the presence of eggs in the frames. The eggs, removed from their cells and placed in free flying colonies were either ejected or eaten by workers. At the concentrations 1 and $10 \mathrm{mg} \cdot \mathrm{kg}^{-1}$, bees reared brood during 12 weeks and the amounts of larvae obtained was equal to those reared by the bees feeding on the control diet. Free flying colonies fed 3.51 of a sucrose solution at $100 \mathrm{mg} \cdot \mathrm{kg}^{-1}$ Bay Sir, contained 2 to 3 day old larvae and dead pupae one week following the treatment. Eighteen days after the initial test feeding, the colonies had new healthy sealed brood. When the concentration was $150 \mathrm{mg} \cdot \mathrm{kg}^{-1}$, the colonies examined 6 days after feeding, contained no young larvae and 2 weeks after feeding all pupae were removed. Normal brood was observed only 3 weeks after the initial feeding. At $200 \mathrm{mg} \cdot \mathrm{kg}^{-1}, 11$ days after feeding, no brood was present and all pupae died.

\subsection{Risk assessment after field treatment with an IGR}

\subsubsection{Fenoxycarb}

In experiments conducted from 1982 to 1984, Gerig (1985) observed bee colonies foraging apple tree orchards which were treated with fenoxycarb (Insegar ${ }^{\circledR}$ ) during flowering period. He sampled pollen collected by honey bees, sorted apple and pear pellets, and found residues ranging from 1.9 to $18 \mathrm{mg} \cdot \mathrm{kg}^{-1}$ fenoxycarb. After tests using more or less contaminated pollens fed to newly emerged workers, Gerig concluded that fenoxycarb sprayed on flowering orchards was not likely to cause damage to honey bees since the compound must be diluted through mingling of species and be present only in insignificant amounts. Besides, during the years 1983 and 1984, no damage on bees was reported. Although these results may have been due to the lack of appropriate methods of investigation, the author recommended this material should not be applied during foraging periods. During the years 1983-1988 Gerig (1991) found damaged brood in colonies foraging orchards sprayed with fenoxycarb at $200 \mathrm{~g} \cdot \mathrm{ha}^{-1}$ and $600 \mathrm{~g} \cdot \mathrm{ha}^{-1}$. Maximum residues in mixed pollens collected by bees ranged from $1.93 \mathrm{mg} \cdot \mathrm{kg}^{-1}$ to $11.3 \mathrm{mg} \cdot \mathrm{kg}^{-1}$, respectively. Studies conducted with colonies visiting rape grown under cages showed that sprays at the dose rates of $200 \mathrm{~g} \cdot \mathrm{ha}^{-1}$ and $600 \mathrm{~g} \cdot \mathrm{ha}^{-1}$ were hazardous to brood, whereas $20 \mathrm{~g} \cdot \mathrm{ha}^{-1}$ were tolerated. The authors recommended that fenoxycarb should not be applied to flowering fruit trees and that flowering weeds should be eliminated before treatment. Moreover, care should be taken to avoid drifting to neighbouring attractive crops (Arzone et al., 1989). De Ruijter and van der Steen (1987) sprayed a 12 ha orchard with $700 \mathrm{mg} \cdot \mathrm{kg}^{-1}$ a.i. fenoxycarb and $200 \mathrm{l} \cdot \mathrm{ha}^{-1}$ and observed the brood of four colonies in the treated crop and two in a control orchard. They marked eggs, young larvae, old larvae and capped cells on overhead sheets 3 times a week and noted the first damage 10 days after application. Contaminated larvae developed into pupae that died at the capped stage and all brood which reached the second larval phase within 5 days after spraying, died. Malformed individuals with white rimmed eyes could be found for 10 days and abnormal mortality of pupae was noted for 12 days. 


\subsubsection{Diflubenzuron}

After treatment of apple orchards in full bloom at 110, 200 and $400 \mathrm{~g} \cdot \mathrm{ha}^{-1}$ diflubenzuron Emmet and Archer (1980) did not find any damage in adult bees or brood of colonies foraging the treated flowers. Small quantities of residues $\left(0.11\right.$ and $0.39 \mathrm{mg} \cdot \mathrm{kg}^{-1}$ diflubenzuron) were determined in honey from these colonies. Bauml (1982) reported that diflubenzuron sprayed at $75 \mathrm{~g} \cdot \mathrm{ha}^{-1}$ on spruce forests did not affect colony weight and brood rearing in 3 hives placed in the treated area. Robinson (1979) studied the effects of a total of 8 spray treatments with diflubenzuron applied at one week interval on cotton fields. Two doses were tested: $140 \mathrm{~g} \cdot \mathrm{ha}^{-1}$ and $35 \mathrm{~g} \cdot \mathrm{ha}^{-1}$, and colonies were examined before and after each spaying. Adult bee activity and brood development assessed by marking individual cells, were not affected. Residues were not detected in any wax, honey or pollen sample from colonies foraging the plot treated at the lower rate but in the other plot treated at $140 \mathrm{~g} \cdot \mathrm{ha}^{-1}$, pollen samples from the hives contained 0.06 to $0.19 \mathrm{mg} \cdot \mathrm{kg}^{-1}$ diflubenzuron. As no residues could be detected in other hive products, it was concluded that residues in pollen resulted from a direct contamination by the spray after the pellets dropped in the trap. Because experimental plots were small, the author presumed foragers dispersed on competing nectar and pollen sources and that their exposure to residues was limited. Therefore, further tests should be conducted in places where large areas are treated in order to confirm these preliminary results. Egger (1977) found that an aircraft application of diflubenzuron in a forest supplying a good honeydew flow caused little damaged brood in bee colonies foraging the honeydew 11 days after spraying. Twenty five days after treatment similar losses in larvae, prepupae and pupae were still observed though at a lower extent. After 8 aerial applications at $350 \mathrm{~g} \cdot \mathrm{ha}^{-1}$ diflubenzuron on Citrus, Schroeder et al. (1980) examined the brood of hives either placed in a 4 ha treated grove or in an adjacent control grove. Over a period of 7 months, the authors could not observe any difference between the sealed brood of the treated hives and that of the check. Moreover no residues were detected in honey collected after the sprays. Robinson and Johansen (1978) found that spraying forests at 140 or $280 \mathrm{~g} \cdot \mathrm{ha}^{-1}$ diflubenzuron caused no damage to adults or brood in hives placed in the treated area and examined 10 and 46 days after the spray. These dose rates resulted in residues in pollen of 1.2 and $6.2 \mathrm{mg} \cdot \mathrm{kg}^{-1}$ respectively (Davis et al., 1978).

\subsection{Registration of IGR treatments on crops and risk assessment}

According to a recent Directory (ACTA, 2001) four chitin inhibitors and four hormone mimics have been registered in France for pest control in crops which can be foraged by bees (Tab. II). Target pests generally belong to Lepidoptera, Homoptera, Coleoptera and Acarina, harmful to maïze, fruit trees, vine, vegetables and ornamental flowers. The highest dose $\cdot \mathrm{ha}^{-1}$ is $168 \mathrm{~g} \cdot \mathrm{ha}^{-1}$ of tebufenozide to control Lepidoptera of pear trees, and the lowest is $25 \mathrm{~g} \cdot \mathrm{ha}^{-1}$ of pyriproxyfen to control white flies (Aleurodes) on tomatoes. None of these compounds is systemic.

Laboratory and field data (Tab. III) show that even at the highest dose rate $\left(400 \mathrm{~g} \cdot \mathrm{ha}^{-1}\right)$ diflubenzuron sprays did not affect honey bee brood. This is in accordance with the laboratory data. Residues of diflubenzuron in pollen were maximum $\left(6.2 \mathrm{mg} \cdot \mathrm{kg}^{-1}\right)$ after spraying forests at $280 \mathrm{~g} \cdot \mathrm{ha}^{-1}$ while no residues could be detected after a treatment of cotton at $35 \mathrm{~g} \cdot \mathrm{ha}^{-1}$. In honey, maximum residues were $0.39 \mathrm{mg} \cdot \mathrm{kg}^{-1}$ when dose rate ranged from 110 to $400 \mathrm{~g} \cdot \mathrm{ha}^{-1}$. If the maximum registration rate is $125 \mathrm{~g} \cdot \mathrm{ha}^{-1}$ (Tab. II), residues in bee forage are expected to be lower than $6.2 \mathrm{mg} \cdot \mathrm{kg}^{-1}$ and $0.39 \mathrm{mg} \cdot \mathrm{kg}^{-1}$ in pollen and honey respectively. In semi-field feeding tests with diflubenzuron, Wilson 
Table II. Registration of 8 IGRs in France (ACTA, 2001).

\begin{tabular}{|c|c|c|c|c|}
\hline Mode of action & Active substance & Crop & Target pest & Dose $g \cdot h^{-1}$ \\
\hline Chitin inhibitor & Diflubenzuron & $\begin{array}{c}\text { Maïze } \\
\text { Fruit trees } \\
\text { Forest trees }\end{array}$ & $\begin{array}{l}\text { Sesamia } \\
\text { Cydia } \\
\text { Bombyx }\end{array}$ & $75-125$ \\
\hline Chitin inhibitor & Flufenoxuron & $\begin{array}{c}\text { Vine } \\
\text { Fruit trees }\end{array}$ & $\begin{array}{l}\text { Mites } \\
\text { Cydia }\end{array}$ & $40-100$ \\
\hline Chitin inhibitor & Hexaflumuron & $\begin{array}{c}\text { Potato } \\
\text { Fruit trees }\end{array}$ & $\begin{array}{l}\text { Leptinotarsa } \\
\text { Psylla, Cydia }\end{array}$ & $35-125$ \\
\hline Chitin inhibitor & Lufenuron & $\begin{array}{c}\text { Vine } \\
\text { Ornamental } \\
\text { plants }\end{array}$ & $\begin{array}{l}\text { Lobesia } \\
\text { Thrips }\end{array}$ & $50-150$ \\
\hline Hormone mimic (Ecdysone) & Tebufenozide & $\begin{array}{c}\text { Vine } \\
\text { Fruit trees }\end{array}$ & $\begin{array}{l}\text { Lobesia } \\
\text { Cydia }\end{array}$ & $144-168$ \\
\hline $\begin{array}{l}\text { Hormone mimic } \\
\text { (anti-Ecdysone) }\end{array}$ & Buprofenozin & Vegetables & Aleurodes & 132 \\
\hline Hormone mimic $(\mathrm{JH})$ & Fenoxycarb & $\begin{array}{c}\text { Vine } \\
\text { Fruit trees }\end{array}$ & $\begin{array}{l}\text { Lobesia } \\
\text { Cydia } \\
\text { Saissetia }\end{array}$ & $75-150$ \\
\hline Hormone mimic $(\mathrm{JH})$ & Pyriproxyfen & Tomato & Aleurodes & 25 \\
\hline
\end{tabular}

(1982) assessed a lowest observable effect concentration of $1 \mathrm{mg} \cdot \mathrm{kg}^{-1}$ while the highest non observable effect concentration was $50 \mathrm{mg} \cdot \mathrm{kg}^{-1}$ (Tomic et al., 1985). Such discrepancies may be due to the different environmental conditions of the two field tests and can be interpreted in the worst case as a consequence of an exceptional low dilution of the contaminated food by external floral resources. Therefore, diflubenzuron treatments can be regarded as generally safe for dose rates up to $125 \mathrm{~g} \cdot \mathrm{ha}^{-1}$. However some damage can not be excluded if environmental conditions do not allow enough dilution of the contaminated food.

In mixed pellets from bees foraging in an area where orchards were treated at $200 \mathrm{~g} \cdot \mathrm{ha}^{-1}$ and $600 \mathrm{~g} \cdot \mathrm{ha}^{-1}$ fenoxycarb, residues reached $1.93 \mathrm{mg} \cdot \mathrm{kg}^{-1}$ and $11 \mathrm{mg} \cdot \mathrm{kg}^{-1}$ respectively (Gerig, 1991). The damage caused to brood was in agreement with the LC 50 of $0.2 \mathrm{mg} \cdot \mathrm{kg}^{-1}$. The reduced dose of $140 \mathrm{~g} \cdot \mathrm{ha}^{-1}$ applied to orchards was also harmful to brood (de Ruijter and Van der Steen, 1987).

The LD 50 and LC 50 of fenoxycarb and diflubenzuron estimated for Apis mellifica and $B$. terrestris larvae show a greater tolerance of $B$. terrestris to fenoxycarb which is harmless to this species when applied at doses up to $1200 \mathrm{~g} \cdot \mathrm{h}^{-1}$ (Tab. III). Therefore applying fenoxycarb at $140 \mathrm{~g} \cdot \mathrm{h}^{-1}$ will be safe for bumble bee larvae but will cause damage to honey bee brood. Conversely $B$. terrestris young larvae are more susceptible to diflubenzuron than honey bee larvae. This explains losses in young brood of bumble bee colonies exposed to crops sprayed at $300 \mathrm{~g} \cdot \mathrm{ha}^{-1}$ which is a dose rate safe for honey bees. 
Table III. Oral toxicity of two IGRs to honey bee and bumble bee larvae and risk assessment after application to test crops.

\begin{tabular}{|c|c|c|c|c|c|c|c|}
\hline IGR & Species & $\begin{array}{c}\text { LD } 50 \\
\text { (ng.bee }{ }^{-1} \text { larva) }\end{array}$ & $\begin{array}{c}\mathrm{LC} 50 \\
\left(\mathrm{mg} \cdot \mathrm{kg}^{-1}\right)\end{array}$ & Crop & $\begin{array}{c}\text { Dose } \\
\left(\mathrm{g} \text { a.i. } \cdot h a^{-1}\right)\end{array}$ & $\begin{array}{l}\text { Residues } \\
\text { in pollen or honey } \\
\left(\mathrm{mg} \cdot \mathrm{kg}^{-1}\right)\end{array}$ & Effects \\
\hline Fenoxycarb & $\begin{array}{c}\text { Apis } \\
\text { mellifera }\end{array}$ & $\begin{array}{c}7 \text { [2 day queen la.* }{ }^{*} \text { (a) } \\
17 \text { [2 day worker la.] (a) } \\
16 \text { [2 day male la.] (a) }\end{array}$ & 0.2 (a) & $\begin{array}{l}\operatorname{orchard}(\mathrm{e}) \\
\operatorname{orchard}(\mathrm{f})\end{array}$ & $\begin{array}{c}200-600(\mathrm{e}) \\
140(\mathrm{f})\end{array}$ & $1.9-11$ [ро.*] (e) & $\begin{array}{l}\text { damaged brood (e) } \\
\text { damaged brood (f) }\end{array}$ \\
\hline Diflubenzuron & $\begin{array}{c}\text { Apis } \\
\text { mellifera }\end{array}$ & 2420 [3 day la.] (c) & $3.7(d)$ & $\begin{array}{l}\text { orchard }(\mathrm{g}) \\
\text { cotton }(\mathrm{h}) \\
\text { Citrus }(\mathrm{i}) \\
\text { forest }(\mathrm{j}, \mathrm{k})\end{array}$ & $\begin{array}{c}110-400(\mathrm{~g}) \\
35-140(\mathrm{~h}) \\
350(\mathrm{i}) \\
140-280(\mathrm{j}, \mathrm{k})\end{array}$ & $\begin{array}{c}0.11-0.39 \text { [ho.*] (g) } \\
0-0.19 \text { [po.] (h) } \\
0 \text { [ho.] (i) } \\
1.2-6.2 \text { [po.] (j, k) }\end{array}$ & $\begin{array}{c}\text { none }(\mathrm{g}) \\
\text { none }(\mathrm{h}) \\
\text { none }(\mathrm{i}) \\
\text { none }(\mathrm{j}, \mathrm{k})\end{array}$ \\
\hline Fenoxycarb & $\begin{array}{l}\text { Bombus } \\
\text { terrestris }\end{array}$ & $\begin{array}{c}>650 \text { [ } 1 \text { day la.] (l) } \\
>3710 \text { [6 day la. }(1)\end{array}$ & $\begin{array}{c}>100 \\
{[1-6 \text { day la. }](1)}\end{array}$ & Phacelia (1) & $1200(1)$ & $\begin{array}{l}217 \text { [day 1] (1) } \\
7.5 \text { [day 7] (1) }\end{array}$ & none (1) \\
\hline Diflubenzuron & $\begin{array}{l}\text { Bombus } \\
\text { terrestris }\end{array}$ & $\begin{array}{c}7.7 \text { [1 day la.] (l) } \\
5112 \text { [6 day la.] (1) }\end{array}$ & $\begin{array}{c}1.18 \\
{[1 \text { day la.] (1) }} \\
137.8 \\
{[6 \text { day la.] (1) }}\end{array}$ & Phacelia (1) & $300(1)$ & $\begin{array}{l}62 \text { [day 1] (1) } \\
2 \text { [day 7] (1) }\end{array}$ & damaged brood (1) \\
\hline
\end{tabular}

* la. = larva, po.= pollen, ho. = honey.

Nitsch and Vorwohl, 1992 (a), Czoppelt, 1991 (b), Chandel and Gupta, 1992 (c), Wittman, 1982 (d), Gerig, 1991 (e), De Ruijter and Van der Steen, 1987 (f), Emmet and Archer, 1980 (g), Robinson, 1979 (h), Shroeder et al., 1980 (i), Robinson and Johansen, 1978 (j), Davis et al., (1978) (k), Gretenkord and Drescher, 1996 (l) 


\section{EFFECTS OF IGRS ON NON-APIS BEES}

\subsection{Methods for testing IGRs on bumblebees}

\subsubsection{Laboratory tests}

De Wael et al. (1995) comparing the effects of several IGRs on B. terrestris, used queen-right colonies, each containing 30 to 50 workers. They were kept in the dark at $29{ }^{\circ} \mathrm{C}$ and fed daily with $50 \%$ sugar solution and pollen collected from honey bees. Test IGRs were administrated in syrup for $24 \mathrm{~h}$, then the amount ingested was determined by weight loss. Dead adults and larvae were removed and counted daily and photographs of the nest were taken daily for 5 weeks. As photographic records started a week before treatment it was possible to estimate the effect of IGRs on the development of all brood stages, from egg to pupa. The authors used only one colony per treatment and a control colony fed with sucrose solution.

As bumble bee larvae can not be isolated successfully in vitro as it is done with honey bees, Gretenkord and Drescher (1996) devised a larval test adapted to bumble bees. They prepared "test groups" by removing egg cells from colonies until hatching, and equalising the number of larvae in all the groups. They obtained standard cells with 10 young larvae which were each kept at $29{ }^{\circ} \mathrm{C}$ in rearing boxes $(12.5 \times 7 \times 5 \mathrm{~cm})$ with 3 nurse workers. Test groups were fed syrup and pollen dough until pupation. The workers were then removed until adults emerged. For testing IGRs it was recommended that 1,4 and 6 day old larvae be fed separately for $24 \mathrm{~h}$ with pollen dough or syrup in which the test substance was dissolved. Trials, comprising 3 replicates of each treatment and control, should start with the recommended concentration for field use. If negative effects are observed, the trials should continue with lower concentrations. From the mortality records and food consumption measurements per larva, LC 50 and LD 50 should be calculated.

\subsubsection{Cage and greenhouse tests}

The same authors modified a cage test method previously devised for conventional compounds testing (Gretenkord and Drescher, 1993). In their new procedure (Gretenkord and Drescher, 1996), colonies of 50-70 workers were placed in cages $(3 \times 4 \times 2 \mathrm{~m})$ covering Phacelia plots. When about 10 foragers could be observed, colonies were moved to the laboratory and foragers left in the cage. The colonies were reduced to 5 workers with the queen and a defined amount of brood of all stages. These colonies were then reintroduced into their cage and foragers could go back to their nest thus forming standardised units which could develop with flower resources and syrup but without additional pollen feeding. This procedure allowed an accurate assessment of the effects of contamination of pollen by an IGR on brood. The test substance should be sprayed on Phacelia the day following colony reduction. After a cage period of 2-3 weeks, colonies should be reared in the laboratory for 2 weeks until adult emergence.

Tornier (1999) described a test method adapted to the greenhouse. He used 4 queenright colonies per treatment, with 30 workers and similar amounts of brood. Photographs of each brood clump were taken before and after application. All adults were marked before the colonies were introduced into the greenhouse and a trap was fixed at the hive entrance for collecting dead adults and larvae. Three parameters were recorded during the test period: the food consumption, the weight of colonies and the wing size of adults.

Thompson and Barrett (1999) also tested IGRs in a greenhouse. They used $5 \times 3 \mathrm{~m}$ compartments containing tomato plants and a single queen-right colony with 100-200 workers. Tomato was treated at 10 days intervals. Colonies were fed additional pollen which was also treated at the same rate as plants. Each IGR treatment and the control spray with water were repeated in 
2 compartments. Diflubenzuron at $0.03 \%$ a.i., was used as a "positive" control. From day 3 to day 23, the authors monitored the number of dead adults, dead larvae, foraging bees and the general appearance of the colonies.

\subsubsection{Field tests}

Schäfer and Mühlen (1996) conducted a field trial to test the effects of an IGR on B. terrestris by placing 6 colonies of approximately 50 workers each in a $2400 \mathrm{~m}^{2}$ Phacelia field. Before and after treatment the following parameters were determined: the density of foragers the flight activity at the hive entrance, the origin and amount of the pollen collected, the number of workers, the mortality of larvae, and the number of egg cells, larvae and cocoons. There was no observation beyond the fourth day after treatment. The authors concluded their procedure did not allow a correct interpretation of the data and that standardisation of such method was not easy due to the unpredictable development of bumble bee colonies.

\subsection{Effects of IGRs on bumble bees}

\subsubsection{Effects on adults}

In a greenhouse test diflubenzuron sprayed on tomatoes at the concentration $0.03 \%$ a.i. proved harmless to adults (Thompson and Barrett, 1999). Fenoxycarb applied at $1200 \mathrm{~g} \cdot \mathrm{ha}^{-1}$ to Phacelia grown in cages, did not cause any trouble to caged adults of the test colonies (Gretenkord and Drescher, 1993). In a Phacelia field, Schäfer and Mühlen (1996) found that an application of triflumuron at $800 \mathrm{~g} \cdot \mathrm{ha}^{-1}$ did not influence flight activity of experimental colonies.

\subsubsection{Effects on brood}

When pyriproxyfen at $20 \mathrm{mg} \cdot \mathrm{kg}^{-1}$ a.i. was fed to colonies for $24 \mathrm{~h}$ and compared to fenoxycarb at $100 \mathrm{mg} \cdot \mathrm{kg}^{-1}$ a.i. and tefluben- zuron at $150 \mathrm{mg} \cdot \mathrm{kg}^{-1} \mathrm{~g}$ a.i. De Wael et al. (1995) found that the last treatment resulted in a higher larval mortality than the control and the two other IGRs. With teflubenzuron, larvae died and were all removed by workers during the week following treatment. In addition, the queen continued to lay eggs but egg development was arrested for 5 weeks. Fenoxycarb and pyriproxyfen did not cause any damage to brood.

Testing two IGRs on one and 6 day old larvae, Gretenkord and Drescher (1996) reported an LC 50 higher than $100 \mathrm{mg} \cdot \mathrm{kg}^{-1}$ for fenoxycarb for both ages, while that for diflubenzuron was 1.18 and $137.79 \mathrm{mg} \cdot \mathrm{kg}^{-1}$, respectively. The LD 50 of fenoxycarb was higher than 650 and $3710 \mathrm{ng} \cdot \mathrm{bee}^{-1}$ for one and 6 day old larvae respectively. For diflubenzuron, the LD 50 was 7.7 and $5112.0 \mathrm{ng} \cdot \mathrm{bee}^{-1}$ respectively. In a cage test where both compounds were sprayed at a normal and double dose (i.e. 600 and $1200 \mathrm{~g} \cdot \mathrm{ha}^{-1}$ fenoxycarb and 300 and $600 \mathrm{~g} \cdot \mathrm{ha}^{-1}$ diflubenzuron) residues in pollen ranged from $217 \mathrm{mg} \cdot \mathrm{kg}^{-1}$ the first day to $7.5 \mathrm{mg} \cdot \mathrm{kg}^{-1}$ fenoxycarb the seventh day, and from $62 \mathrm{mg} \cdot \mathrm{kg}^{-1}$ diflubenzuron the first day to $2 \mathrm{mg} \cdot \mathrm{kg}^{-1}$ the seventh day. In all of the five test cages with fenoxycarb, no brood damage and no malformed adults were detected while in the eight cages with diflubenzuron all the larvae died, except old ones, within the 2 days following treatment. During 3 weeks no brood was reared though egg laying continued, which suggested a negative effect on the queen's ovaries. Moreover the authors observed malformed cocoons which were spherical with abnormal brown dots on the surface. Fenoxycarb was safe for caged bumble bees though the concentration in pollen on the first day was twice the concentration fed to larvae in the laboratory test. Diflubenzuron residues in pollen even after the seventh day following application were within the range of the LC 50 values for one to 4 day old larvae, but residues on the first day did not reach the LC 50 for 6 day old larvae which was in 
accordance with the survival of the old brood in the caged colonies.

\subsection{Effects of IGRs on other wild pollinators}

Kawashima (1989) tested 3 chitin synthesis inhibitors, diflubenzuron, chorfluazuron and teflubenzuron on the orchard pollinator, the solitary bee Osmia cornifrons, by spraying bees directly and confining them with treated apple leaves. The three IGRs affected neither the survival of adults nor cocoon formation. Presumably the effects on progeny would have been different if $O$. cornifrons had the chance to forage on treated flowers and provision their cells with contaminated pollen. Narita (1988) did not find any damage in adult $O$. cornifrons released on trees 3 days after spraying the plants with solutions at 25 and $50 \mathrm{mg} \cdot \mathrm{kg}^{-1}$ of chlorfluazuron and flufenoxuron respectively.

De Oliveira Campos (1978) tested the juvenile hormone analogue Altozar ${ }^{\circledR}$ on larvae of the social bee Melipona quadrifasciata. Topical applications of $18.3 \mu \mathrm{g} \cdot \mathrm{larva}^{-1}$ to larvae spinning their cocoon promoted the transformation of female worker larvae into queen pupae and male pupae into female adults.

\section{CONCLUSION}

Insect growth regulators, used for pest control management will cause no damage to adult honey bees and probably other adult pollinators, and can be considered as safer for foragers than second generation insecticides. Oral and contact laboratory tests and field observations or trials proved adults tolerated these compounds, in particular at the registered doses.

This safety for pollinators is only apparent, since serious damage to brood has been reported in honey bees and bumble bees. Abnormal mortality in eggs, larvae or pupae and typical malformations have been observed in colonies after some IGR applications. These troubles were due to the properties of these products, which all interfere with embryo development and moulting process and which contaminate food resources collected (nectar and pollen) and stored in the colony by foragers. As a consequence, the effects of intoxication by IGRs are always delayed. They also cover a longer period than in the case of non-IGR insecticides. These characteristics justify new testing of laboratory and field methods for toxicity and risk assessment.

Comparison of data from tests with $A$. mellifera and $B$. terrestris proved these two species were affected in opposite ways by the application of the same IGR. Therefore, risk assessment for one test species can not be extended to others without appropriate additional investigations.

Résumé - Effets des régulateurs de croissance des insectes sur les abeilles domestiques et les abeilles sauvages. Les régulateurs de croissance des insectes ou RCI ou encore insecticides de la troisième génération agissent comme des ecdysones, des hormones juvéniles ou des inhibiteurs de chitine. Ce sont des composés synthétiques ou des substances naturelles comme l'Azadirachtin, qui interfèrent dans l'équilibre naturel des hormones de mue. De ce fait, ils risquent peu de produire des dommages chez les adultes, par contre ils peuvent engendrer des troubles dans le couvain. L'application d'analogues d'hormones à des abeilles adultes a modifié le comportement de butinage, la production de phéromone d'alarme, l'hémolymphe, le gain de poids, la synthèse de la vitellogénine, la longévité et a inhibé les glandes hypopharyngiennes (Redfern et Knox, 1974 ; Jaycox et al., 1974 ; Rutz et al., 1974 ; Gerig, 1975 ; Atkins et al., 1976 ; Robinson, 1985 ; Usha et Kadasamy, 1986 ; Ceparano et Job, 1989 ; Gupta et Chandel, 1995 ; Pinto et al., 2000). Chez les larves l'intoxication expérimentale 
par contact ou par ingestion provoque la mort des œufs, des larves, ou des malformations des larves, des nymphes ou des adultes. Les nymphes ont alors des yeux atypiques portant un cercle coloré. Il y a aussi possibilité d'inhibition des glandes hypopharyngiennes et d'apparition de caractères royaux. Larves et nymphes intoxiquées sont éjectées des cellules par les ouvrières (Zdarek et Haragsim, 1974 ; Beetsma et Ten Houten, 1975 ; Gerig, 1975 ; Hrdy et Skrobal, 1976 ; Hussein et Abdel-Aal, 1978 ; Rembold et al., 1980, 1982 ; El Din et al., 1990 ; Gerig, 1990 ; Van der Steen et de Ruijter, 1990 ; Marletto et al., 1992 ; Chandel et Gupta, 1992 ; Nitsch et al., 1994 ; Gromisz et Gromisz, 1996).

Plusieurs méthodes ont été publiées pour tester la toxicité des RCI sur les larves (Barker et Taber, 1977 ; Wittman, 1982 ; Atkins et Kellum, 1986 ; Engels, 1990 ; Czoppelt, 1990 ; Van der Steen et De Ruijter, 1990 ; Naumann et Isman, 1996). La plupart des données proviennent d'expérimentations sur deux produits le fenoxycarb et le diflubenzuron, testés sur l'abeille et les bourdons Bombus terrestris. Chez l'abeille, selon les auteurs les concentrations dans la nourriture, sans effets par ingestion, varient de 1 à $50 \mathrm{mg} \cdot \mathrm{kg}^{-1}$ de diflubenzuron (Barker et Taber, 1977 ; Barker et Waller, 1978 ; Czoppelt et Rembold, 1981 ; Wittman, 1982 ; Stoner et Wilson, 1982 ; Tomic et al., 1985 ; Nation et al., 1986 ; Chandel et Gupta, 1992). Le fenoxycarbe provoque la mort de $100 \%$ des nymphes à 1a concentration de $0,5 \mathrm{mg} \cdot \mathrm{kg}^{-1}$ de substance active (Czoppelt, 1991). En champ, aux doses expérimentales (35 à $400 \mathrm{~g} \cdot \mathrm{ha}^{-1}$ ) le diflubenzuron est estimé sans danger pour les colonies par la plupart des auteurs, au contraire du fenoxycarbe qui cause des dommages au couvain à $140 \mathrm{~g} \cdot \mathrm{ha}^{-1}$ (de Ruijter et Egger 1977 ; Robinson et Johansen, 1978 ; Robinson, 1979 ; Emmet et Archer, 1980 ; Schroeder et al., 1980 ; Bauml, 1982 ; Van der Steen, 1987 ; Arzone et al., 1989). Chez B. terrestris on a trouvé que les traitements à $1200 \mathrm{~g} \cdot \mathrm{ha}^{-1}$ de fenoxycarbe n'avaient pas d'effet négatif sur les larves alors que le diflubenzuron entraînait de sévères pertes chez les larves et les œufs à la dose de $300 \mathrm{~g} \cdot \mathrm{ha}^{-1}$. Ces résultats on été corroborés par des tests sur larves en laboratoire qui ont permis d'évaluer les DL 50 des 2 insecticides sur plusieurs stades larvaires (Gretenkord et Drescher, 1996).

\section{régulateur croissance insecte / Apis mellifera / Bombus / abeille sauvage / évaluation risque}

\section{Zusammenfassung - Auswirkungen von} Wachstumsregulatoren der Insekten auf Honigbienen und Wildbienen. Die Wachstumsregulatoren der Insekten, auch als IGR oder Insektizide der 3. Generation bezeichnet, wirken wie Ecdyson, Juvenilhormon oder greifen in die Chitinsynthese ein. Es handelt sich dabei sowohl um synthetische Verbindungen als auch um natürliche Substanzen wie z.B. Azadirachtin (vom Neem Baum), die in das Gleichgewicht des Hormonhaushalts während des Wachstums eingreifen. Dadurch sind sie bei adulten Tieren weniger gefährlich, im Gegensatz dazu können sie bei der Brut Schäden hervorrufen. Die Applikation der Hormonanaloge bei adulten Bienen hat Einfluss auf das Sammelverhalten, die Produktion des Alarmpheromons, die Hämolymphe, die Gewichtszunahme, die Vitellogeninsynthese, die Lebenserwartung und hemmt die Entwicklung der Hypopharynxdrüsen (Redfern und Knox, 1974; Jaycox et al., 1974; Rutz et al., 1974; Gerig, 1975, Atkins et al., 1976; Robinson, 1985; Usha und Kadasamy, 1986; Ceparano und Job 1989; Gupta und Chandel, 1995; Pinto et al., 2000). Bei der Brut führt die experimentelle Giftapplikation zum Absterben der Eier und Larven oder zu Verkrüppelungen der Larven, Puppen oder erwachsenen Tiere. Die Puppen haben demzufolge atypische Augen, die einen gefärbten Kreis aufweisen. Außerdem entstehen Hemmungen der Hypopharynxdrüsen und es kommt zur Ausbildung von Königinnenmerkmalen. Vergiftete Larven und Puppen werden von den Arbeiterinnen aus den Zellen entfernt (Zdarek und 
Haragsim, 1974; Beetsma und Ten Houten, 1975; Gerig, 1975; Hrdy und Skrobal, 1976; Hussein und Abdel-Aal, 1978; Rembold et al., 1980, 1982; El Din et al., 1990; Gerig, 1990; Van der Steen und de Ruijter, 1990; Marletto et al., 1992; Chandel und Gupta, 1992; Nitsch et al., 1994; Gromisz und Gromisz, 1996).

Es wurden verschiedene Methoden publiziert um die Toxizität der IGRs auf Larven zu testen (Barker und Taber, 1977; Wittman, 1982; Atkins und Kellum, 1986; Engels, 1990; Czoppelt, 1990; Van der Steen und De Ruijter, 1990; Naumann und Isman, 1996). Die meisten der Arbeiten weisen Versuche mit 2 Produkten, Fenoxycarb und Diflubenzuron auf, die bei Honigbienen und Hummeln Bombus terrestris geprüft wurden. Solange die Konzentrationen in der Nahrung bei adulten Honigbienen zwischen $1 \mathrm{bis} 50 \mathrm{mg} \cdot \mathrm{kg}^{-1}$ betrugen, ergaben sich nach den Autoren keine Wirkung (Barker und Taber, 1977; Barker und Waller, 1978; Czoppelt und Rembold, 1981; Wittman, 1982; Stoner und Wilson, 1982; Tomic et al., 1985; Nation et al., 1986; Chandel und Gupta, 1992). Fenoxycarb bewirkt bei einer Konzentration von $0,5 \mathrm{mg} \cdot \mathrm{kg}^{-1} \mathrm{der}$ aktiven Substanz zu $100 \%$ den Tod von Puppen (Czoppelt, 1991). Bei Behandlungen im Feld mit einer Dosierung von 35 bis $400 \mathrm{~g} \cdot \mathrm{ha}^{-1}$ gilt das Diflubenzuron bei den meisten Autoren als für Bienenvölker ungefährlich, im Gegensatz zu Fenoxycarb, das Schäden bei der Brut bei einer Konzentration $140 \mathrm{~g} \cdot \mathrm{ha}^{-1}$ erzeugt (de Ruijter und Egger, 1977; Robinson und Johansen, 1978; Robinson, 1979; Emmet und Archer, 1980; Schroeder et al., 1980; Bauml, 1982; Van der Steen, 1987; Arzone et al., 1989). Bei $B$. terrestris fand man, dass Behandlungen mit $1200 \mathrm{~g} \cdot \mathrm{ha}^{-1}$ Fenoxycarb keinen negativen Effekt auf die Larven hat, während Diflubenzuron bei einer Konzentration von $300 \mathrm{~g} \cdot \mathrm{ha}^{-1}$ schwere Verluste bei Eiern und Larven zur Folge hatte. Diese Ergebnisse wurden durch Untersuchungen mit Larven im Labor unterstützt, mit der die Bestimmung der LD 50 dieser beiden Insektizide auf verschiedene Larvenstadien erfolgte (Gretenkord und Drescher, 1996).

Insektenwachstumsregulatoren / Honigbienen / Wildbienen / Toxizität / Risikoabschätzung

\section{REFERENCES}

A.C.T.A. (2001) Index phytosanitaire ACTA, Association de Coordination Technique Agricole, 149 rue de Bercy, Paris.

Anonymous (1989) L'Insegar et les abeilles. Nouvelles prescriptions, Rev. Suisse Vitic. Hortic. 21, 64-65.

Atkins E.L., Anderson L.D., Kellum D., Neuman K.W (1976) Protecting honey bees from pesticides. Leaflet 2883, University of California.

Atkins E.L., Kellum D. (1986) Comparative morphogenic and toxicity studies on the effect of pesticides on honeybe brood, J. Apic. Res. 25, 242-255.

Arzone A., Dolci M., Marletto M. (1989) Detection of fenoxycarb on mulberry leaves, Apic. Mod. 80, 149-152 (in Italian).

Barker R.J., Taber S. (1977) Effects of diflubenzuron fed to caged honey bees, Environ. Entomol. 6 , 167-168.

Barker R.J., Waller G.D. (1978) Effects of diflubenzuron wettable powder on caged honey bee colonies, Environ. Entomol. 78, 535-574.

Bauml W. (1982) Field studies on the effects of Dimilin on the honey bee, Anz. Schaedlingskd. Pflanzen. Umweltsch. 55, 97-101 (in German).

Beetsma J., Ten Houten A. (1975) Effects of juvenile hormone analogues in the food of honey bee colonies (Apis mellifera L.), Z. Angew. Entomol. 77, 292-300.

Ceparano G., Job S. (1996) Flucycloxuron: a new acaricide, Inf. Fitopatol. 46, 32-34.

Chandel R.S., Gupta P.R. (1992) Toxicity of diflubenzuron and penfluron to immature stages of Apis cerana indica $\mathrm{F}$. and Apis mellifera L., Apidologie $23,465-473$.

Czoppelt C. (1990) Effect of insect growth inhibitors and pesticides on honey bee larvae (Apis mellifera L.) in contact poison and feeding tests in vitro, Proceedings of the 4th International Symposium on Harmonization of Methods for Testing the Toxicity of Pesticides to Bees, May 15-18, Rez near Prague, Research Institute of Apiculture, Dol, Czechoslovaquia 1990, pp. 76-83.

Czoppelt C. (1991) Evaluation of toxicity of the juvenoid phenoxycarb to honeybee larvae reared in vitro, Apidologie 22, 457-459.

Czoppelt C., Rembold H. (1981) Effects of Dimilin on the growth of honey bee larvae reared in an incubator, Mitt. Dtsch. Ges. Allg. Angew. Entomol. 3 , 1-13; 191-195 (in German). 
Davis E.J., Robinson W.S., Roush C.F., Akre R.D., Johansen C.A., Turner W.J. (1978) Impact of chemical control applications for the Douglas-fir Tussock moth on beneficial insects including biological studies of bees, yellowjackets, and flesh flies, Melanderia 30, 1-7.

Davis A.R. (1989) The study of insecticide poisoning of honeybee brood, Bee World 70, 163-174

Davis A.R., Solomon K.R., Shuel R.W. (2000) Laboratory studies of honeybee larval growth and development as affected by systemic insecticides at adultsublethal levels, J. Apic. Res. 27, 146-161.

Egger A. (1977) The side effect of Dimilin on honeybees, an investigation in relation to aircraft application in forests. Zentralblatt für Gesamte Forstwesen 94, 5-72 (in German).

El-Din H.A., El-Samni M.A., Attia M.B. (1990) Latent effects of some insect growth regulators on the body weight of workers of the honey bee Apis mellifera L. var. carnica (Hym. Apidae), Anz. Schaedlingskd. Pflanzen. Umweltsch. 63, 67-68.

Emmett B.J., Archer B.M. (1980) The toxicity of diflubenzuron to honey bee (Apis mellifera L.) colonies in apple orchards, Plant. Pathol. 29, 177-183.

Engels W. (1990) Testing of insect growth regulators and of varroacides by Apis-larvae test, Proceedings of the 4th International Symposium on Harmonization of Methods for Testing the Toxicity of Pesticides to Bees, May 15-18, Rez near Prague, Research Institute of Apiculture, Dol, Czechoslovaquia 1990, pp. 84-87.

George D.A., Rincker C.M. (1985) Results and conclusions of using pesticides with the alfalfa leafcutting bee in the production of alfalfa seed, J. Agric. Entomol. 2, 93-97.

Gerig L. (1975) The effects of juvenile hormone analogues on summer bees (Apis mellifera L.) in the field and laboratory, Schweiz. Landwirtsch. Forsch. 14, 355-370 (in German).

Gerig L. (1985) Treatment of blooming orchard trees with fenoxycarb, Proceedings of the 3rd International Symposium on Harmonization of Methods for Testing the Toxicity of Pesticides to Bees, 18-21 March 1985, Rothamsted, UK, Appendix 16.

Gerig L. (1990) News about the use of Insegar (fenoxycarb) in Switzerland, Proceedings of the 4th International Symposium on Harmonization of Methods for Testing the Toxicity of Pesticides to Bees, May 15-18, Rez near Prague, Research Institute of Apiculture, Dol, Czechoslovaquia 1990, pp. 74-75.

Gerig L. (1991) Importance de l'Insegar pour l'apiculture et 1'arboriculture, J. Suisse Apic. 88, 235-238.

Gretenkord C., Drescher W. (1996) Laboratory and cage test methods for the evaluation of the effects of growth regulators (Insegar, Dimilin) on the brood of Bombus terrestris L., Proceedings of the 6th International Symposium on Hazards of Pesticides to Bees, Sept. 17-19, 1996, Braunschweig, Germany, Appendix 29.
Gretenkord C., Drescher W. (1993) Development of a cage test method for the evaluation of pesticide hazards to the bumble bee Bombus terrestris L., Proceedings of the 5th International Symposium. on the Hazards of Pesticides to Bees, Oct. 26-28, Wageningen, The Netherlands, Appendix 20.

Gromisz Z., Gromisz M. (1996) Harmful effects of the Nomolt formulation on honey bees, Pszcz. Zesz. Nauk. 40, 175-183 (in Polish).

Grosscurt A.C. (1978) Diflubenzuron: Some aspects of its ovicidal and larvicidal mode of action and an evaluation of its practical possibilities, Pestic. Sci. 9, 373-386.

Gupta P.R., Chandel R.S. (1995) Effects of diflubenzuron and penfluron on workers of Apis cerana indica F. and Apis mellifera L., Apidologie 26, $3-10$.

Herbert E.W., Argauer R.J., Shimanuki H. (1986) The effect of an insect chitin synthesis inhibitor on honey bees, Apidologie 17, 73-76.

Hrdy I., Skrobal D. (1976) Effect of two juvenoids on honey bee colonies (Apis mellifera L.), Apidologie 7, 39-47 (in German).

Hussein M.H., Abdel-Aal Y.A.I. (1978) Effect of ZR 515 on honey bee, Apis mellifera L., Z. Angew. Zool. 87, 109-111.

Kawashima K. (1989) Effect of chitin inhibitors on the horn faced, Osmia cornifrons Radoskowski, J. Soc. Plant Prot. North Jpn. 40, 171-173 (in Japanese).

Jaycox E.R., Skowronek W., Guynn G. (1974) Behavioral changes in worker honey bees (Apis mellifera) induced by injections of juvenile hormone mimic, Ann. Entomol. Soc. Am. 67, 529-534.

Marletto F., Arzone A., Dolci M. (1992) Action of fenoxycarb on honey bee brood, Apic. Mod. 83, 209-218 (in Italian).

Marletto F., Arzone A., Dolci M. (1997) The honey bee as a biological indicator of fenoxycarb pollution, Apic. Mod. 88, 107-110 (in Italian).

Narita T. (1988) Control of the tortrix (Archips fuscocupreana Walsingham) on apple trees by chitin synthesis inhibitors, Kitanippon Byogaichu Kenkyukaiko 39, 242-245 (in Japanese).

Nation J.L., Robinson F.A., Yu S.J., Bolten A.B. (1986) Influence upon honey bees of exposure to very low levels of selected insecticides in their diet, J. Apic. Res. 25, 170-177.

Naumann K., Isman M.B. (1996) Toxicity of a neem (Azadirachta indica A. Juss) insecticide to larval honey bees, Am. Bee J. 136, 518-520.

Nitsch C., Vorwohl G. (1992) The effect of Insegar on the honey bee, Allg. Dtsch. Imkerztg. 26, 6-8 (in German).

Nitsch C., Horn H., Vorwohl G. (1994) Effect of Dimilin on queen rearing, Dtsch. Bienen. J. 2, 16-19 (in German).

Oliveira Campos L.A. de (1978) Sex determination in bees. VI. Effect of juvenile hormone analogue in males and females of Melipona quadrifasciata (Apidae), J. Kans. Entomol. Soc. 51, 228-234. 
Oomen P.A., Ruijter A., Steen J. van der (1992) Method for honey bee brood feeding tests with insect growth-regulating insecticides, EPPO Bull. 22 613-616.

Pinto L.Z., Bitondi M.M., Simoes Z.L.P. (2000) Inhibition of vitellogenin synthesis in Apis mellifera workers by juvenile hormone analogue pyriproxyfen, J. Insect Physiol. 46, 153-160.

Redfern R.E., Knox D.A. (1974) Adult honey bee relative toxicity of two juvenile hormone analogues, Am. Bee J. 456-458.

Rembold H., Sharma G.K., Czoppelt C., Schmutterer H. (1980) Evidence of growth disruption in insects without feeding inhibition by neem seed fractions, Z. Pflanzenkd. Pflanzenschutz. 87, 290-297.

Rembold H., Czoppelt C. (1981) Evaluation of insect growth regulators from Azadirachta indica (neem) using rearing tests on honey bee larvae, Mitt. Dtsch Ges. Allg. Angew. Entomol. 3, 196-198 (in German).

Rembold H., Lackner B. (1981) Rearing of honeybee larvae in vitro: effect of yeast extract on queen differentiation, J. Apic. Res. 20, 165-171.

Rembold H., Sharma G.K., Czoppelt C., Schmutterer H. (1982) Azadirachtin: a potent insect growth regulator of plant origin, Z. Angew. Entomol. 93, 12-17

Robinson F.A. (1979) The effects of repeated spray applications of Dimilin W-25 on honey bee colonies in cotton fields, Am. Bee J. 119, 193-194; 197.

Robinson F.A. (1985) Effects of a juvenile hormone analogue on bee foraging behaviour and alarm pheromone production, J. Insect Physiol. 31, 277-282.

Robinson F.A., Johansen C.A. (1978) Effects of control chemicals for douglas fir tussock moth on forest pollination, Melanderia 30, 9-56.

Ruijter A. de, Steen J. van der (1987) A field study on the effect on honey bee brood of Insegar (fenoxycarb) applied on blooming apple orchard, Apidologie 18, 355-357.

Rutz W., Gerig L., Wille H., Lüscher M. (1974) A bioassay for juvenile hormone $(\mathrm{JH})$ effects of insect growth regulators (IGR) on adult worker honey bees, Preliminary report, Mitt. Schweiz. Entomol. Ges. 47, 307-313.

Schäfer H., Mühlen W. (1996) First experiences to test side-effects of Alsystin on bumble bees (Bombus terrestris L.) in the field, Proceedings of the 6th International Symposium on Hazards of Pesticides to Bees, Sept. 17-19, 1996, Braunschweig, Germany, Appendix 30.

Schroeder W.J., Sutton R.A., Beavers J.B. (1980) Diaprepes abbreviatus: Fate of diflubenzuron and effect on non-target pests and beneficial species after application to Citrus for weevil control, J. Econ. Entomol. 73, 637-638.

Steen J. van der, Ruijter A. de (1990) Test methods to determine the hazards of IGRs (insect growth regulators) on honey bee brood, using phenoxycarb as an example, Proceedings of the 4th International Symposium on Harmonization of Methods for Test- ing the Toxicity of Pesticides to Bees, May 15-18, Rez near Prague, Research Institute of Apiculture, Dol, Czechoslovaquia 1990, pp. 88-91.

Stoner A., Wilson W.T. (1982) Diflubenzuron (Dimilin): effect of long-term feeding of low doses in sugar cake or sucrose syrup on honey bees in standard-size field colonies, Am. Bee J. 122, 579-582.

Tasei J.N., Carré C. (1987) Effects of the pyrethroid insecticide WL85871 and phosalone on adults and progeny of the leaf-cutting bee Megachile rotundata F., pollinator of lucerne, Pestic. Sci. 21 119-128.

Tasei J.N., Carré C., Moscatelli B., Grondeau C. (1988 Recherche de la DL50 de la deltaméthrine (Decis) chez : Megachile rotundata $\mathrm{F}$, abeille pollinisatrice de la luzerne et des effets de doses infraléthales sur les adultes et les larves, Apidologie 19, 291-306.

Thompson H.M., Barrett K.A. (1990) Assessing the effects of glasshouse application of a novel insect growth regulator on bumble bee colonies, in: Belzunces L.P., Pélissier C., Lewis G.B. (Eds.), Hazards of pesticides to bees, Proc. 7th Int. Symp. on Hazards of Pesticides to Bees 7-9 Sept 1999, Avignon, France, INRA Paris, pp. 227-228.

Tomic N., Popescovic D., Dujin N. (1985) Some larval and post-larval effects of diflubenzuron on honey bee (Apis mellifera L.), Proceedings of the 29th International Congress of Apiculture, Budapest, 1983, Apimondia Publishing House, Bucharest, Romania, pp. 275-278.

Tornier I. (2001) Side effects of an Insect growth regulator on bumble bees and honey bees, in: Belzunces L.P., Pélissier C., Lewis G.B. (Eds.), Hazards of pesticides to bees, Proc. 7th Int. Symp. on Hazards of Pesticides to Bees, 7-9 Sept. 1999, Avignon, INRA Editions, Paris, les Colloques $\mathrm{n}^{\circ}$ 98, 299.

Usha K., Kandasamy C. (1986) Comparative toxicity of certain pesticides to the honey bee Apis indica F., Pest. Manage. 1, 31-35.

Wael L., de Greef M., de Laere O. Van (1995) Toxicity of pyriproxyfen and fenoxycarb to bumble bee brood using a new method for testing insect growth regulators, J. Apic. Res. 34, 3-8.

Webster T.C., Peng Y.S. (1989) Short term and longterm effects of methamidophos on brood rearing in honey bee (Hymenoptera: Apidae) colonies, J. Econ. Entomol. 82, 69-74.

Wigglesworth V.B. (1972) The principles of insect physiology, 7th ed., Chapman and Hall, London, UK.

Williams C.M. (1956) The juvenile hormone of insects, Nature 178, 212-213.

Wittmann D. (1982) Determination of the LC50 of Dimilin 25 WP for honey bee brood on free flying colonies as an example for the use of a new Apislarvae-test, Apidologie 13, 104-107.

Zdarek J., Haragsim O. (1974) Action of juvenoids on metamorphosis of the honey bee, Apis mellifera, J. Insect Physiol. 20, 209-221. 